\title{
Szigetvári Tamás: Európai integráció és/vagy keleti nyitás. Török külpolitikai és külgazdasági dilemmák a 21. század elején
}

\section{Typotex, Budapest, 2018, 236 o.}

Szigetvári Tamás Törökországról szóló monográfiája hiánypótló munka a magyar szakirodalomban. Központi dilemmája az, hogy az ország „a Nyugat legkeletibb és a Kelet legnyugatibb" (9. o.) részeként az Európai Unióhoz csatlakozzon-e, vagy önálló regionális szerepre törjön, és hídként müködjön Kelet és Nyugat között. A kérdés megválaszolásában a szerző egyszerre vizsgál történeti, politikai, gazdasági és vallási szempontokat, amelyek egyaránt befolyásolják a török külpolitika folyamatos hullámzását az Európával való konfliktus és kooperáció között.

A kötet első része az Oszmán Birodalom kialakulásától a 20. század végéig mutatja be a török politikát, gazdaságot és külpolitikát.

Az iszlám, majd az Oszmán Birodalom sokáig az európai államok első számú ellensége volt, ám idővel betagozódott az európai hatalmi rendszerbe. Fénykorában sikerét arra alapozta, hogy nagymértékben megtürte a birodalmon belül a sokféleséget - a szabad vallásgyakorlás jóval hamarabb jelen volt, mint Nyugaton (16-18. o.). Kínától Afrikáig fenntartott kapcsolatai révén meghatározó jelentőségủ volt az európai kereskedelemben, bár ez a szerep csökkent az alternatív kereskedelmi utak felfedezésével. Szigetvári nem ért egyet azzal, hogy az iszlám önmagában gátja lett volna a kapitalizmus kialakulásának, hisz Mohamed is kereskedő volt, és a vallás pragmatikus módon áll az anyagi haszonszerzéshez. Később idézi azt is, hogy Mohamed szerint „egyedül Allah irányítja a piacot” (93. o.). Az Oszmán Birodalom hanyatlását, ami a 19. századra az „Európa beteg embere” címet eredményezte, elsősorban a növekvő finanszírozási igényekre és az adóbehajtás - decentralizáció miatti - alacsony hatékonyságára vezeti vissza, amelyek jelentős hátránynak bizonyultak a nemzetállami keretben kialakult kapitalizmushoz képest.

A lemaradás elkerülése érdekében a birodalom a 18. századtól igyekezett átvenni a nyugati fejlesztéseket a hadviselésben, illetve a jog- és intézményrendszerben, ám ez komoly ellenállásba ütközött a hadsereg elitje, illetve a vallási tanítók részéröl. A reformokat így jelentős késéssel vezették be, miközben folyamatosan veszítettek területeket, egyre növekedett a külső befolyás, és a helyi ipar sem tudott megerösödni.

A kézirat első változata 2019. február 19-én érkezett szerkesztőségünkbe.

DOI: http://dx.doi.org/10.18414/KSZ.2019.4.467 
A legtöbb nagy infrastrukturális beruházás külföldi tőke révén valósult meg, elsősorban francia, német és brit forrásokból. A magas államadósság kezelésére külön hivatal jött létre a hitelezők képviselöiből, amelyek számos modernizációs reformot kényszerítettek a birodalomra. Ez a külső kényszer azonban jelentős ellenérzéseket is keltett, és megerösödött a muszlim közösséghez tartozás tudata. A félgyarmati sors elutasítása vezette 1914-ben az országot a németekkel való szövetséghez. A háborút lezáró 1920. évi sèvres-i béke revíziójaként megszületett 1923. évi lausanne-i békeszerződés teremtette meg a szuverén Törökország alapjait.

Az első köztársasági elnök Musztafa Kemál lett, a felszabadító háború hőse, aki az európai civilizáció átvételében látta az ország jövőjét, míg az iszlámot az elmaradottság felelősének tartotta. A kemali reformok teljesen el kívánták törölni a korábban érvényes iszlám jogrendszert és hagyományokat. A kezdetben plurális vezetés azonban egyre autoriterebb lett, és 1931-re már egypártrendszert hoztak létre, ahol állami és pártfunkciók szorosan összefonódtak. A gazdaságban az államilag vezérelt fejlődés volt a jellemző, a szovjetekkel együttmüködve, akik a nehézipar markáns fejlesztését javasolták. Az erőteljes állami beavatkozás a gazdaságot az államtól tette függővé. Külpolitikában az ország a status quo híve volt, és ki kívánt maradni a második világháborúból - csak 1945-ben üzentek hadat a németeknek, és váltak a győztes szövetség tagjává.

A második világháború után Törökország a nyugati szövetség oszlopos tagja lett, és az amerikaiak a politikai és gazdasági nyitást szorgalmazták. 1950-ben az ellenzéki Demokrata Párt győzött, azaz elkezdődött az egyetlen párt uralmára épülő rendszer lebontása. Ezúttal a vidéki, mezőgazdaságból élő népesség támogatását helyezték előtérbe, és a kedvező külgazdasági környezetben az ország 11-13 százalékos növekedést tudott felmutatni. Szintén igyekeztek csökkenti az állam gazdasági szerepét. Az 50-es évek második felében azonban a konjunktúra lelassult, és az ennek kompenzálására bevezetett szubvenciók inflációt gerjesztettek, és költségvetési hiányt eredményeztek. A vidéki szavazóbázis megtartásának érdekében engedményeket tettek a hétköznapi vallásgyakorlás számára, ami miatt a pártot az atatürki hagyományok elárulójának tartották, és 1960-ban katonai puccs megbuktatta. Menderest és a kormánya néhány tagját kivégezték, a Demokrata Pártot betiltották. Az új alkotmány számos féket és ellensúlyt épített be a rendszerbe, és különböző koalíciós kormányok követték egymást, amelyek hatékonysági problémákkal küzdöttek. A gazdaságban az állam domináns szerepe és a zárt gazdasági modell fennmaradt, annak ellenére, hogy Törökország 1963-ban társulási szerződést írt alá az Európai Gazdasági Közösséggel. Az importhelyettesítő iparosítás elérte a korlátait - verseny hiányában a török ipar nem vált versenyképessé, és a fizetési mérleg hiánya miatt 1979-ben az IMF-hez kellett fordulnia. A kormányzásképtelenségre hivatkozva a hadsereg 1980-ban ismét átvette a hatalmat.

A következö évtizedben az állami beavatkozások csökkentése, az importhelyettesítő politika helyett az exportorientáció és a külföldi befektetések vonzása került a középpontba. Ez az irány sikeresnek bizonyult, az export megduplázódott, és szerkezete is eltolódott az agrártermékektől az ipari termékek irányába. A politikában is liberalizáció vette kezdetét, eltörölték a vallási és osztályalapon szerveződö pártalapítás tilalmát. 
Ennek köszönhetően immár iszlamista pártok is részt vehettek a közéletben. Az 1999es földrengést és pénzügyi válságot követően, 2002-ben az Igazság és Fejlődés Pártja (AKP) nyerte a választásokat Tayyip Erdogan vezetésével.

A könyv második része Erdogan Törökországát tekinti át az ezredforduló óta. Az iszlamista pártok vallási háttere az iszlám szufi irányzata, amely a személyes istentapasztalatot hangsúlyozza. A rendszer nem hierarchikus, hanem lazább, hálózatszerü szervezetek révén müködik, amelyek a félillegalitás állapotában különösen hasznosnak bizonyultak. Az iszlamista pártok kezdetben ellenségesek voltak az Európai Unióval szemben, amelyet keresztény országok klubjának tartottak, és féltek attól, hogy a külföldi tőke megszállja az országot. Az erős állami beavatkozást pártolták, és a demokratikus rendszerhez ambivalens módon álltak hozzá. Az ezredfordulóra azonban e nézetek mérséklődését lehetett megfigyelni. Az európai integráció kapcsán felismerték, hogy az EU demokratikus követelményei a hadsereg befolyását korlátozzák, míg a szólásszabadság az iszlamisták erőteljesebb közszereplését teszi lehetővé. A muszlim vállalkozói réteg számára növekvő piacbarátságukat hangsúlyozták. Erdogan és az AKP programja így vonzóvá vált a globalizációs folyamat győzteseinek és veszteseinek egyaránt, míg a szekuláris erők által képviselt, hagyományos állam vezérelte modernizáció legitimációs válságban volt.

Az AKP kormányzása három szakaszra osztható. Az első szakaszban a gyors gazdasági növekedés, demokratizálás és az EU-tárgyalások megkezdése önerösítő pozitív kört alkotott. Az AKP klasszikus jobbközép pártként viselkedett, elismerte a demokrácia, az emberi jogok, a jogállamiság és a pluralizmus értékeit. Az EU-csatlakozási tárgyalások megkezdéséhez életbe léptetett reformok a demokratizáció irányába mutattak - biztosították a szólásszabadságot, és csökkentették a hadsereg befolyását. Második ciklusa során az AKP igyekezett a hadsereget meggyengíteni, mivel egyre növekvő veszélye volt a beavatkozásnak - különösen a fejkendőviselés újbóli engedélyezését követően. A következő ciklusban, 2011-től az AKP hatalmának monopolizálása irányba mozdult el. Ez a média szabadságának korlátozását, a bírói rendszerre gyakorolt nyomást és az AKP-hoz hü üzleti körök kedvezményezését jelentette. Ezt a folyamatot tetőzte be a 2016-os puccskísérlet, ami után előre kitervelten számoltak le ellenfeleikkel. A könyv nem vizsgálja, hogy a puccsot valóban a hadsereg szervezte-e, vagy a kormány által megrendezett volt.

A gazdaságban az iszlamista gazdaságpolitika lett a meghatározó. Ennek összetevői a szigorú antiinflációs monetáris politika, a szelektív iparpolitika, az öngondoskodás és a családközpontú berendezkedés a szociális politikában, illetve a gazdaságdiplomáciára alapuló külkapcsolatok erősítése. Az ezredforduló utáni első évtizedet dinamikus növekedés jellemezte, amikor számos nemzetközi autógyártó cég érkezett az országba, és az elektronika és a jármügyártás a török gazdaság húzóágazatává vált. A 2008/2009-es válság idején az ország saját erőből talpon maradt, azaz nem volt szükség az IMF behívására, és jelentős keresletösztönző lépéseknek is volt tere. Mindezek ellenére a szerző rámutat arra, hogy az olcsó munkaeröre építő stratégia nem fenntartható. Az oktatás fejlesztése és a további működőtőke-vonzás a fejlődéshez elkerülhetetlen. Az utóbbi évek romló politikai helyzete miatt azonban müködőtőke 
helyett egyre inkább forró tőke áramlik az országba. A kötet megírása után kitört valutaválság és tőkemenekülés 2018 nyarán megerősíti a szerző állításait.

A külpolitikában az iszlamista kormány szakított a korábban egyoldalú Nyugat-orientációval, és önálló regionális szerepre tört. Ennek jegyében 2003-ban nem támogatta az amerikai intervenciót Irakban, és célként tűzte ki a szomszédokkal való kétoldalú kapcsolatok javítását. Ennek alapja a „nulla probléma” elve lett, illetve jelentős erőfeszítéseket tettek a „szelíd erő” (soft power) eszközeinek felhasználására is, például a török filmipar alkotásaival. Az elképzelések szerint a hidegháború után a gazdasági kapcsolatok a döntőek, és Törökország a kereskedóállam képének igyekezett megfelelni. Mindez az arab tavasz kitöréséig müködött, amikor ismét elötérbe kerültek a biztonsági megfontolások. 2016-ban az új külpolitika kidolgozója, Ahmet Davotoğlu távozott a hatalomból, és kérdéses, hogy utána mi következik. Mindenesetre a külpolitikai változásokat a külkereskedelmi szerkezet váltása is kísérte - az EU súlya 50 százalék alá csökkent, míg a Közel-Kelet súlya 14-ről közel 28 százalékra nőtt 2007 és 2016 között. Az import esetében Kína és Oroszország növekvő részesedése látható. A működőtőke 75 százaléka azonban továbbra is az EU-ból érkezik.

\section{A kötet harmadik része Törökország külpolitikai kapcsolatait részletezi.}

A török külpolitikában a legfontosabb az EU-val való viszony - az ország már 1964 óta társult tag, és 1996 óta vámuniót is alkot az unióval. Szigetvári Tamás szerint a vámunió létrehozása elsősorban identitásbeli kérdés volt, és jelentős költségekkel jár Törökország számára, mivel az átlagos vámszint csökkenését eredményezte úgy, hogy ezeknek a megállapítására az országnak nincs befolyása, és az EU szabadkereskedelmi megállapodásai rájuk nem vonatkoznak. Az áldozatok ellenére azonban a török csatlakozást súlyos kétségek övezik. A könyv részletesen leírja, hogy melyek ezek a kétségek: Ciprus sorsa, az olcsó török munkaerő beáramlásától való félelem, a demokrácia és a jogállamiság hiánya, illetve az iszlám megítélése. Végleges elutasítás és elfordulás azonban nincs, az EU és Törökország kiemelt partnerként tekintenek egymásra - ez a partnerség kulcsszerepet játszott például a 2015-ös migrációs válság megoldásában.

Az ország csatlakozási esélyeit jelentősen formálja az egyes tagállamokkal való kapcsolat, különösen a német-török viszony. Ez a kapcsolat sokáig rendkívül szoros volt, ám a 2016-os puccskísérletet követő leszámolások, majd az új alkotmány 2017-es bevezetése komoly konfliktust eredményezett, és a német befektetőket is elbizonytalanította. A németekkel szemben az osztrákok 70-80 százaléka ellenzi a csatlakozást - részben nettó befizetőként, részben identitásalapon. Ezeket az ellenérzéseket Törökország autoriter fordulata is felerősítette a Benelux és a skandináv államokban is. Franciaország az iszlám térnyerése miatt belpolitikai okokból ódzkodik a török csatlakozástól. A törököket sokáig támogatták a britek, ám a brexitkampányban lehetséges csatlakozásuk már a kilépés melletti érvként merült fel. Törökország támogatói jelenleg elsősorban a mediterrán országok, Spanyolország és Olaszország. Szintén alacsony az elutasítottsága a keleti tagállamokban, amelyek érdekalapon állnak a külpolitikához.

A török-EU kapcsolatok legvalószínübb kimenete Szigetvári Tamás szerint a tagság valamilyen alternatívája, egyfajta privilegizált partnerség, amelynek keretében olyan területeken törekszenek szorosabb együttmüködésre, ahol kölcsönösen 
előnyös megállapodások köthetők. Ilyen terület a külpolitika, az energetika, illetve a kereskedelmi kapcsolatok. Amennyiben ez nem valósul meg, Törökország alternatív kapcsolatokat keres Keleten - csatlakozhat a Shaghaji Együttmüködési Szervezethez vagy az Eurázsiai Gazdasági Unióhoz. Ezek a felvetések azonban a szerző szerint inkább fenyegetésnek tekinthetők - a migráció és a gazdasági kapcsolatok szorosan összekötik Törökországot az Európai Unióval.

Az új török külgazdasági stratégiában elsősorban a szomszéd régióknak van kiemelt jelentőségük, amelyek korábban az Oszmán Birodalom részei voltak. Az elmúlt évtizedben a Balkánnal való kereskedelem ötszörösére nőtt, bár itt is az EUtagországoknak (Bulgária, Románia és Görögország) van meghatározó szerepük, amelyek a kereskedelem 85 százalékát adják. Törökország a régióban növekvő mértékben fektet be, például a török építőipari vállalatok meghatározó szereplői a román építőiparnak. Törökország aktívvá vált a muszlim identitáshoz kötődő kulturális szervezetek támogatásában is - Albániában, Koszovóban és Boszniában török iskolák és egyetemek kezdték meg müködésüket.

A Balkán mellett a török irányváltásban a közel-keleti és észak-afrikai (Middle East and North Africa region, MENA) régió tölt be kiemelkedö szerepet. Itt már jóval komolyabb politikai ellentétekkel kell megküzdeniük, a vízhozam-megállapodásoktól a kurd kérdésen át az Izraellel való viszonyig. A dinamikusan növekvő gazdaság, illetve az iszlám és a demokrácia sikeres összeházasítása miatt Törökországot sokáig mintaállamnak is tekintették. Az ezredforduló óta a régió valamennyi országával növekedett a török külkereskedelem, a legnagyobb partnerek Irak, Irán, Szaúd-Arábia és Izrael. Az arab tavaszt követő események azonban erősen aláásták a problémamentességre és a külgazdaságra épülő külpolitika esélyeit, miközben a katonai erő (hard power) egyre nagyobb szerepet játszik.

A nagyhatalmak közül Törökországnak kiemelt partnere Oroszország, amellyel korábban és jelenleg is számos érdekkonfliktusa van, ám törekszenek a pragmatikus együttmüködésre. Ezt erösítik a hasonló belpolitikai folyamatok is. A geostratégiai és geopolitikai ellentétek - például az energetikában - azonban nem tesznek lehetővé szorosabb együttmüködést. Az Egyesült Államokkal való kapcsolat a hidegháború után távolról sem felhőtlen, Irak, Szíria és Fethullah Gülen személye miatt is vannak súrlódások. Az Egyesült Államok sokáig a török EU-csatlakozás legfontosabb támogatója volt, azonban az utóbbi évtizedekben inkább kontraproduktívnak bizonyult. Az Egyesült Államok a kereskedelmi partnerek között stabilan az első ötben szerepel az export és az import szempontjából is, illetve a második legnagyobb külföldi befektető. A 2000-es évektől Kínával is megerősödtek a kapcsolatok, bár a muszlim vallású és török etnikumú ujgurok elnyomása komoly konfliktusforrás. Ennek ellenére a kereskedelem a két ország között rendkívül dinamikusan nő, és Törökország részese Kína új selyemút projektjének is, amely a köztes régiók, azaz Közép-Ázsia és Délkelet-Ázsia felé is nyitási lehetőséget kínál.

A kötet zárófejezete a török dilemmákról szól. Megállapítja, hogy az EU nehézségei új piacok szerzésére ösztökélték Törökországot, ám ezek egyelőre elmaradnak az európai piac súlyától. Az ország számára az európai kapcsolat továbbra is elsőbbséget 
élvez, különösen, mivel erősen beépült az európai multinacionális vállalatok termelési értékláncába, amelyek a tőkebeáramlás háromnegyedét adják. A keleti nyitás nem alternatívája az európai kapcsolatoknak, még akkor sem, ha ezek hatására Törökország geopolitikai súlya ténylegesen megnőtt.

Szigetvári Tamás könyve számos adattal és rendkívül tanulságosan mutatja be a Kelet és Nyugat határán fekvő ország politikai, gazdasági és külpolitikai dilemmáit. Törökországban a nyugati, fékekre és ellensúlyokra épülő intézményrendszer meghonosítása csupán a hadsereg védelme alatt volt lehetséges. Az uniós csatlakozással kapcsolatos problémák a hadsereg szerepének csökkentésével és a demokratikus normák betartatásával először Törökország nyugati orientációját ásták alá, majd ez később hozzájárult a demokrácia megroppanásához is. A gazdaságban a kevésbé fejlett gazdaságokra jellemző erős állami beavatkozást váltotta fel a piacbarát, a külföldi működőtőkére építő modell, ám ez a befektetőktől való jelentős függéshez vezetett. Ez a függés pedig azt jelenti, hogy Törökország számára továbbra is meghatározó marad az EU-val való kapcsolat.

Magyar szemmel olvasva a könyvet nem lehet nem észrevenni a párhuzamokat. A politikai rendszer autoriter fordulata, majd az ezt követő gazdaságpolitika és külpolitika komoly hasonlóságokat mutat a két ország között. A legfontosabb tanulság azonban a keleti nyitás lehetőségeivel kapcsolatos - ha a három kontinensen birodalmi múlttal rendelkező Törökország is csupán mérsékelt sikereket ért el a keleti nyitás során, erősen kérdéses, hogyan várhatna Magyarország hasonló politikától komolyabb eredményeket. Az európai integrációnak egyik országban sincs alternatívája.

Győrffy Dóra

Győrffy Dóra egyetemi tanár, PPKE BTK és BCE KTK (e-mail: gyorffy.dora@btk.ppke.hu). 